\title{
Narratiivinen oppiminen elämänkulussa
}

Gert Biesta, John Field, Phil Hodkinson, Flora J. Macleod \& Ivor F. Goodson (2011):

Improving Learning through the Lifecourse. Routledge. $140 \mathrm{~s}$.

ISBN 978-0-415-57373-3

Skotlantilaisen StirlinGIN yliopiston School of Education on osoittautunut siellä harjoitetun tutkimustoiminnan perusteella erittäin tärkeäksi aikuiskoulutuksen ja elinikäisen oppimisen tutkimuskeskukseksi. Laitoksen tutkijoista tunnetuimpia lienevät Richard Edwards, John Field, Gert Biesta, Kathryn Nicoll ja Tara Fenwick, joista useat lähestyvät elinikäistä oppimista foucault'laisittain hallintavallan näkökulmasta. Stirlingin yliopiston tutkijoiden lisäksi Improving Learning through the Lifecourse -kirjan tekoon on osallistunut tutkijoita Leedsin, Exeterin ja Brightonin yliopistoista.

Improving Learning -sarjassa on nyt käsiteltävää teosta ennen ilmestynyt toistakymmentä tutkimusta, joiden johtoajatuksena on tuottaa näyttöön perustuvaa tietoa käytännön ja koulutuspolitiikan tarpeisiin. Kirja perustuu vuosina 2004-2008 toteutettuun poikkeuksellisen laajamittaiseen tutkimushankkeeseen, jossa koottiin ja analysoitiin elämänhistoriallista pitkittäisaineistoa ja isoja survey-aineistoja. Hankkeessa tehtiin muun muassa yli 500 haastattelua ja analysoitiin kotitaloustiedusteluna kerättyjä paneeliaineistoja (British Household Panel Survey; $\mathrm{N}=10000$ ).

\section{OPPIMINEN ON UBIIKKIA, KAIKKIALLISTA}

Kirjan näkökulma oppimiseen rakentuu identiteetin ja toimijuuden käsitteiden varaan. Tutkimus yhdistää elämänhistoriallista (lifehistory) ja tulkitsevaa elämänkulun (lifecourse) tutkimisen metodeita. Ihmisen elämäntarina tai historia on aina henkilön itsensä esittämä tulkinta omasta menneisyydestään. Tulkinnat muuttuvat ajan ja kokemusten myötä. Nykyhetki määrittelee paljolti sitä, millaisen tarinan menneisyydestään henkilö (esimerkiksi haastattelututkimuksessa) kulloinkin luo ja esittää. Menneisyys on läsnä nykyhetkessä ja vaikuttaa olennaisesti siihen, miten ymmärrämme nykyisyyden.

"The present and our stories of the present influence our stories of the past, the past influences the present and our stories of the present, just as our stories of the past influence the present and our stories of the present."

Tutkimus tekee elinikäiseen oppimiseen tärkeän erottelun esittämällä tulokset yhtäältä sen mukaan, mitä tutkittavat ovat oppineet elämänkulussaan ja toisaalta 
mitä he ovat oppineet elämänkulustaan. Jälkimmäisessä tarkastelussa on kysymys metaoppimisesta (joskaan tässä tutkimuksessa metaoppimisen käsitettä ei käytetä): mitä ihminen oppii siitä, miten hänen elämänsä on mennyt? Oma elämä sinällään voi olla ymmärtämisen ja oppimisen kohde. Se, miten ihmiset näkevät oman elämänkulun ja siinä tapahtuneet käänteet ja jatkuvuudet, on mitä tärkein itseymmärryksen ja oppimisen kohde, joskin se jää tutkimuksissa useimmiten tietojen ja taitojen oppimisen varjoon.

Tutkimus todistaa, kuinka suuri osa oppimisesta tapahtuu satunnaisesti ja rutiinimaisesti arkipäivässä. Ihmiset oppivat kaikessa toiminnassaan ja kaikkialla. Oppiminen on ubiikkia, "kaikkiallista" (engl. ubiquity). Se, miten ihmiset näkevät oppimisen, vaihtelee elämänhistorian ja esimerkiksi sosioekonomisen aseman mukaan. Toiset näkevät jatkuvan uusien asioiden oppimisen luontevana osana elämäänsä. Toiset taas ikään kuin havahtuvat huomaamaan oppimisen elämän käännekohtien yhteydessä (esimerkiksi työttömäksi jääminen ja ammatin vaihto, muutto toiselle paikkakunnalle, puolison kuolema). Eikä oppiminen suinkaan ole aina positiivisesti latautunutta: elämässä on kivuliaita käännekohtia, jotka moni olisi jättänyt kokematta; elämä saattaa kääntyä suuntaan, johon ihminen ei olisi sen halunnut kääntyvän. Elämänmuutoksiin joudutaan sopeutumaan. Uutta oppia saadaan kantapään kautta. Elämä on joskus kovaa koulua, josta on oppimisen ilo kaukana.

\section{NARRATIIVIT EDESAUTTAVAT OPPIMISTA}

Elämästä oppimisen ajatukseen liittyy vahvasti yksilön identiteetti. Se, että ihmiset luovat elämästään koherentin kertomuksen, narratiivin, on tutkimuksen mukaan tärkeä keino edesauttaa metaoppimista. Tutkimusryhmä onkin kehitellyt narrativisen oppimisen teoriaa. Narratiivinen oppiminen ei ole suinkaan aina tietoista, vaan tapahtuu ikään kuin yksilön toiminnan, vuorovaikutuksen ja keskustelujen sivutuotteena.

Tukijat käyttävät elämäntarinoiden tutkimisessa narratiivisen laadun käsitettä (narrative quality), joka jakautuu viiteen ulottuvuuteen: (1) narratiivinen intensiteetti, (2) deskriptiivinenanalyyttinen-evaluatiivinen, (3) juoni/juonen rakentaminen,
(4) kronologinen-temaattinen,

(5) teoreettinen-arkikielinen. Elämäntarinoita voidaan luokittaa, tyypitellä ja arvioida niiden narratiivisen laadun perusteella ja näin tehdä havaintoja esimerkiksi erilaisissa oloissa elävien ihmisten oppimisesta ja oppimisen asemasta elämänkulussa.

Narratiivisen laadun ohella tutkimuksessa käytetään vaikutuksen käsitettä (efficacy), joka jakautuu oppimispotentiaaliin (learning potential) ja toimintapotentiaaliin (action potential). Ensimmäisessä on kysymys siitä, missä määrin ja millä tavoilla erilaiset narratiivit edesauttavat oppimista. Jälkimmäinen tarkastelukulma taas kysyy, missä määrin ja millä tavoilla oppiminen (tai opittu) kääntyy toiminnaksi. Kirjaan sisältyy tapaustutkimuksista koostuva jakso, jossa näiden erottelujen avulla käydään läpi useiden haastateltujen elämäntarinoita ja kertomuksia itsestään. Tulkinnat ovat kiintoisaa luettavaa.

\section{KAKSISUUNTAINEN ASETELMA}

Oppimista elämänkulussa käsitellään myös sukupolvierottelujen kautta, jossa brittitutkijat hyödyntävät muun muassa Suomessa tehtyjä tutkimuksia. Kirjassa 
käydään keskustelua kahdesta aikuiskoulutukseen sovelletusta sukupolvijaottelusta. Toinen on peräisin Ari Antikaisen tutkimusryhmän ja toinen Risto Rinteen tutkimusryhmän tutkimuksista. Tutkijat erittelevät useita tekijöitä, joiden seurauksena sukupolvista voi muodostua "koulutuksellisia sukupolvia", jotka eroavat toistaan esimerkiksi koulutuskokemusten ja koulutusasenteiden suhteen. Sukupolvella on tässä mielessä vaikutusta oppimiseen.

Sukupolvi liittyy oppimiseen myös sukupolvien välisen oppimisen (inter-generational learning) kautta. Ihmiskunta on tottunut siihen, että nuorempi sukupolvi saa oppinsa vanhemmilta sukupolvilta. Mutta asetelma on muuttunut yhä enemmän kaksisuuntaiseksi: nykyään vanhemmat sukupolvet ovat usein myös vastaanottavana osapuolena. Esimerkiksi diginatiivit ovat kasvaneet oloihin, joihin sopeutumista vanhempien sukupolvien täytyy oikein opettelemalla opetella. Sukupolviproblematiikan ohella kirja tutkii yhteiskunnallisen aseman ja habituksen vaikutusta oppimiseen.

Kirja on pyritty tekemään nopeasti omaksuttavaksi jakamalla se kolmeen jaksoon seuraavasti:
Mistä asiassa on kysymys? Mitä tutkimus kertoo asiasta? Mitä tästä voidaan päätellä?

Tutkijat tekevät analyysin perusteella aika selkeitä johtopäätöksiä koskien brittiläistä aikuiskoulutuspolitiikkaa. He luettelevat useita puutteita, joihin pitäisi puuttua: aikuiskoulutus on liiaksi keskitetty työllisyyttä palvelevaan tarjontaan, koulutuksen järjestämistä työttömille ja työvoiman ulkopuolella olevalla väestölle ei ole nähty tarpeelliseksi; koulutustarjonta painottuu liiaksi lyhytkestoiseen kurssitukseen, minkä vuoksi pitkäkestoinen omaehtoiseen itsensä kehittämiseen liittyvä koulutus on jäänyt vähäiseksi; koulutuspolitiikassa ja koulutuksen rahoituksessa painottuu liiaksi tutkintoon tähtäävä koulutus.

Aikuiskoulutukseen ja elinikäiseen oppimiseen liittyvää tutkimusta haastattelu- tai kirjoitelmamenetelmällä tekevät löytävät kirjasta hyödyllisiä välineitä aineistojen analysointiin.

Heikki Silvennoinen kasvatustieteen professori Turun yliopisto
IHMISKUNTA ON TOTTUNUT SIIHEN, ETTÄ NUOREMPI

SUKUPOLVI SAA

\author{
OPPINSA
}

VANHEMMILTA. 